\title{
STUDY OF MICROSTRIP PATCH ARRAY ANTENNA FOR SIDE LOBE SUPPRESSION IN THE X-BAND REGION USING UNIFORM, BINOMIAL AND TSCHEBYSCHEFF EXCITATION METHODS
}

\author{
Ahmad Alhadi Ruslan, Sarah Yasmin Mohamad*, \\ KHAIRAYU BADRON, AHMAD FADZIL ISMAIL,

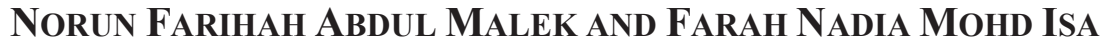 \\ Department of Electrical and Computer Engineering, Faculty of Engineering, \\ International Islamic University Malaysia, \\ P.O. Box 10, 50728 Kuala Lumpur, Malaysia \\ *Corresponding author: smohamad@iium.edu.my
}

(Received: 20 th August 2019; Accepted: $30^{\text {th }}$ October 2019; Published on-line: $20^{\text {th }}$ January 2020)

\begin{abstract}
In this paper, a microstrip patch array antenna is designed and simulated to operate in the X-band frequency region at $9.5 \mathrm{GHz}$. For X-band communication transmission, it is necessary to suppress the side lobe radiation pattern of the antenna as much as possible to avoid the transmission being intercepted and/or received by undesirable neighbouring satellites. The geometrical design of the microstrip patch array antenna is simulated and executed using CST Microwave Studio (CST MWS) in order to study the effects of various antenna parameters such as $S_{11}$, gain, directivity, side lobe level, and angular width. It is shown that the proposed antenna exhibits a low side lobe level of $-14.2 \mathrm{~dB}$ with an acceptable high gain and directivity of $16.5 \mathrm{~dB}$ and $17.7 \mathrm{~dB}$, respectively. The antenna configuration also has a size of only $285 \mathrm{~mm} \times 59.275 \mathrm{~mm}$ which is much more compact and lightweight compared to the standard reflector antennas that are used for most X-band communication transmission.
\end{abstract}

ABSTRAK: Kajian ini berkaitan antena cantuman barisan jalurmikro yang direka dan disimulasi beroperasi pada $9.5 \mathrm{GHz}$ frekunsi daerah jalur-X. Pada transmisi komunikasi jalur-X, corak radiasi sisi-lobus antena perlu ditahan sebanyak mungkin bagi mengelak transmisi dipintas dan/atau diterima oleh satelit tetangga yang tidak di ingini. Rekaan geometri antena cantuman barisan jalurmikro disimulasi dan diuji menggunakan perisian CST Studio Gelombang Mikro (CST MWS) bagi mengkaji pelbagai kesan parameter antenna seperti $S_{11}$, gandaan, keterarahan, tahap sisi-lobus dan lebar sudut. Didapati bahawa antena yang dicadangkan mempunyai tahap sisi-lobus $-14.2 \mathrm{~dB}$ yang rendah dengan gandaan tinggi yang boleh diterima dan keterarahan sebanyak $16.5 \mathrm{~dB}$ dan 17.7 $\mathrm{dB}$, masing-masing. Tatabentuk antena mempunyai saiz $285 \mathrm{~mm} \times 59.275 \mathrm{~mm}$ yang kompak dan ringan berbanding antena pemantul piawai, di mana telah digunakan pada kebanyakan jalur-X transmisi komunikasi.

KEYWORDS: array antenna; microstrip antenna; side lobe suppression; X-band communication

\section{INTRODUCTION}

Microstrip antennas are used for many communication applications and systems due to several advantages. These types of antennas offer benefits in terms of flexibility, 
simplicity, and size [1]. Microstrip antennas are usually compact and very lightweight, making them easily portable compared to other types of antennas such as satellite parabolic dishes or reflector antennas, which are more massive and hefty [2]. They also possess a planar structure and provide low fabrication costs [3]. Moreover, reflector antennas have high side lobe levels that make it possible for other parties to intercept the transmitted signals.

In terms of radiation pattern, most microstrip antennas exhibit a directional pattern, where its radiation intensity is mostly directed in a single direction [4]. These accumulated advantages make it very useful in developing and improving communication systems. Nevertheless, despite all these advantages, microstrip antennas also present some drawbacks. While offering a possible compact size structure, the gain and directivity of the antenna is quite low compared to other directional antennas. This, however, can be solved by improvising the microstrip antennas to operate as an array. Array antennas are a group of single element antennas that are arranged and connected in a regular structure [5]. One of the benefits of using the array configurations are the increase in directivity and gain that cannot be achieved using a single element antenna [6].

In this paper, the microstrip patch array antenna is proposed for use in the X-band communication frequency range $(8-12 \mathrm{GHz})$ [7], specifically at $9.5 \mathrm{GHz}$. The antenna is expected to be compact, portable, exhibit fairly high gain/directivity, and able to reduce the side lobe radiation pattern. As explained earlier, currently used antennas such as parabolic dish antennas have high side lobe levels, as illustrated in Fig. 1. For an excellent $\mathrm{X}$-band communication, the side lobe radiation must be suppressed as much as possible to avoid the transmission being intercepted and/or received by undesirable neighbouring satellites. It should also be noted that much research has been carried out and is still ongoing in order to develop and improve this type of antenna to give better performance [2, 8-12] (summary of recent work can be seen in Table 6). In this project, our proposed microstrip patch array antenna is shown to be able to provide a low side lobe level, with a fairly high gain and directivity, and a compact and lightweight structure.

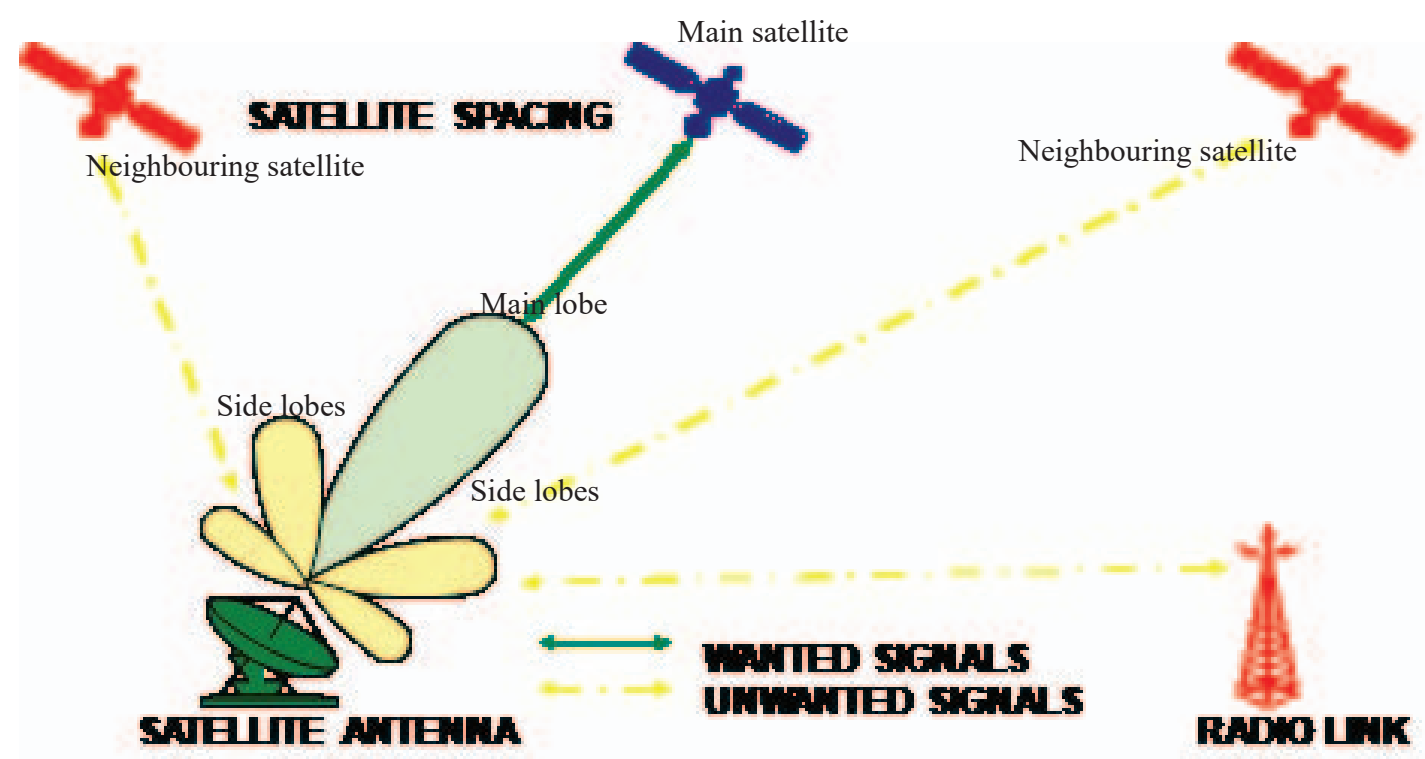

Fig. 1: Parabolic dish antenna radiation pattern with high side-lobe levels. 


\section{DESIGN OF THE MICROSTRIP PATCH ANTENNA}

This paper focused on the design of a microstrip patch array antenna for X-band satellite communication. The antenna is designed to work in the $\mathrm{X}$-band region, specifically at $9.5 \mathrm{GHz}$.

\subsection{Design of the Single Element Microstrip Patch Antenna}

The microstrip patch antenna is initially designed and simulated as a single element (Fig. 2) using a specialized microwave tool, the Computer Simulation Technology (CST) Microwave Studio. The optimized parameters of the antenna are shown in Table 1. The Rogers' RT/duroid 5880 is used as the substrate with a dielectric constant of $\varepsilon_{r}=2.2$, loss tangent of $\delta=0.0009$ and thickness of $t=1.574 \mathrm{~mm}$. The ground plane is designed to be larger than the substrate in order to ensure that the direction of the main beam is set to 0 deg. and also to reduce the back lobe radiation [3].

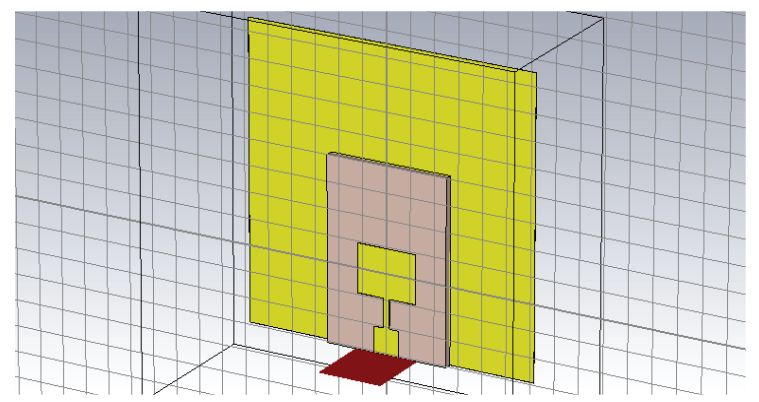

Fig. 2: The single element microstrip patch antenna.

Table 1: Parameters of the single element microstrip patch antenna.

\begin{tabular}{cc}
\hline Parameters & Optimized value \\
\hline Resonant frequency & $9.5 \mathrm{GHz}$ \\
Width of patch & $12.163 \mathrm{~mm}$ \\
Length of patch & $9.318 \mathrm{~mm}$ \\
$\lambda / 4$ feeding line width & $1.344 \mathrm{~mm}$ \\
$50 \Omega$ feeding line width & $5.044 \mathrm{~mm}$ \\
Dielectric material & RT/duroid 5880 \\
Dielectric constant & 2.2 \\
Dielectric height & $1.574 \mathrm{~mm}$ \\
Dielectric length & $35.275 \mathrm{~mm}$ \\
Dielectric width & $25 \mathrm{~mm}$ \\
Ground length & $59.275 \mathrm{~mm}$ \\
Ground width & $60 \mathrm{~mm}$ \\
\hline
\end{tabular}

\subsection{Design of the Microstrip Patch Array Antenna}

The microstrip patch antenna is further improved to be an array with ten elements (Fig. 3) in order to increase the gain and directivity. The ten elements are selected for the array implementation since the array produced the most optimal results in terms of gain and directivity when the elements are increased. The design parameters for the microstrip patch array antenna are shown in Table 2. The spacing between the patch is set at two different spacing, $s=0.5 \lambda$ and $s=0.75 \lambda$, to compare the effect of these parameters to the simulation performances. 


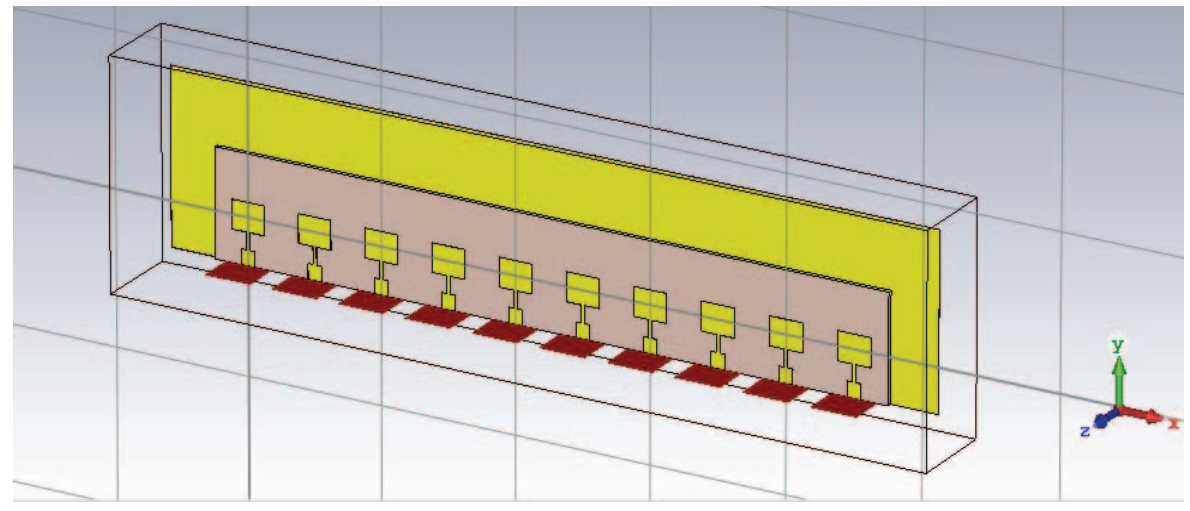

Fig. 3: The microstrip patch array antenna with ten elements.

Table 2: Parameters of the microstrip patch array antenna

\begin{tabular}{cc}
\hline Parameters & Optimized value \\
\hline Resonant frequency & $9.5 \mathrm{GHz}$ \\
Width of patch & $12.163 \mathrm{~mm}$ \\
Length of patch & $9.318 \mathrm{~mm}$ \\
$\lambda / 4$ feeding line width & $1.344 \mathrm{~mm}$ \\
$50 \Omega$ feeding line width & $5.044 \mathrm{~mm}$ \\
Dielectric material & RT/duroid 5880 \\
Dielectric constant & 2.2 \\
Dielectric height & $1.574 \mathrm{~mm}$ \\
Dielectric length & $35.275 \mathrm{~mm}$ \\
Dielectric width & $250 \mathrm{~mm}$ \\
Ground length & $59.275 \mathrm{~mm}$ \\
Ground width & $285 \mathrm{~mm}$ \\
\hline
\end{tabular}

\section{SIMULATED RESULTS}

\subsection{Simulated Results of the Single Element Microstrip Patch Antenna}

The simulated results of the single element microstrip patch antenna using the CST Microwave Studio Software are presented. From Fig. 4, it can be observed that the resonant frequency of the microstrip patch antenna is $9.5 \mathrm{GHz}$ with a $S_{11}$ parameter of $39.11 \mathrm{~dB}$. This proves that the designed antenna radiated well in the intended resonant frequency. Next, the side-lobe level is shown to be $-12.345 \mathrm{~dB}$ (Fig. 5). It is also observed that the angular width of the microstrip patch antenna is very wide $(74.1 \mathrm{deg}$.). This is inconvenient for the intended satellite communication in the X-band, which requires the beam width to be small enough for the transmission of data. This issue can be solved with an array antenna. Moreover, based on Fig. 6, it is observed that the microstrip patch antenna radiated in a directional pattern, where the gain and directivity of the antenna are $7.44 \mathrm{~dB}$ and $8.54 \mathrm{~dB}$, respectively at the main lobe direction of $0 \mathrm{deg}$. The gain and directivity will be further improved by improvising the single element antenna to be working as an array (results in Section 3.2). The simulated results of the single element microstrip patch antenna in terms of gain $(\mathrm{dB})$, directivity $(\mathrm{dB})$, side-lobe level $(\mathrm{dB})$ and angular width (deg.) are summarized in Table 3. 


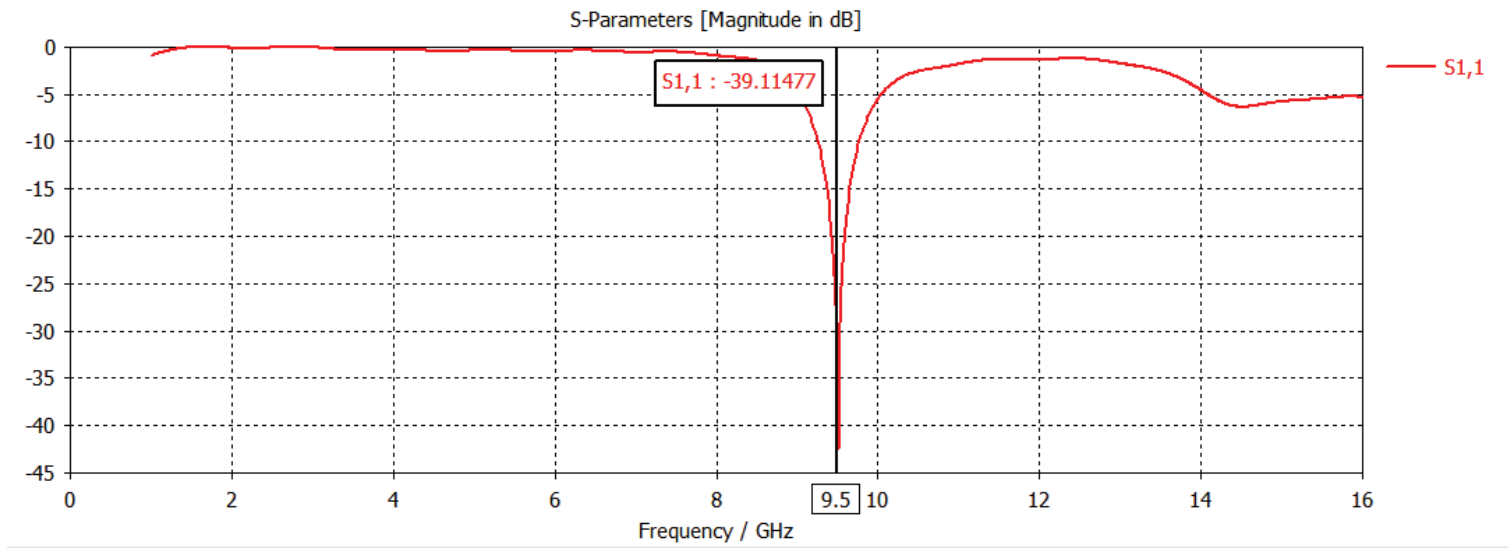

Fig. 4: Return loss for the single element microstrip patch antenna.

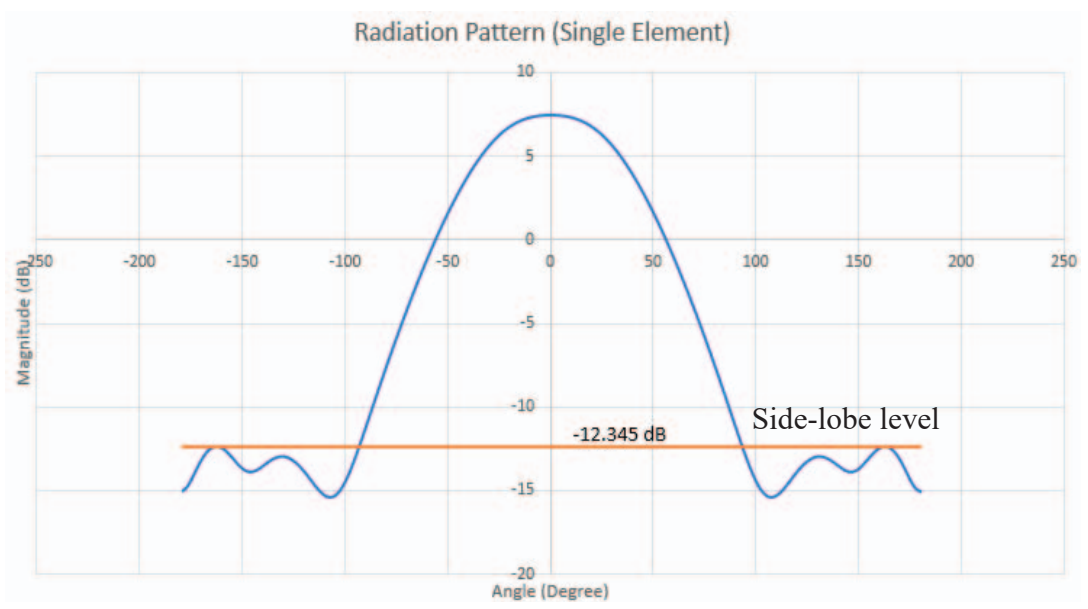

Fig. 5: Side-lobe level for the single element microstrip patch antenna.

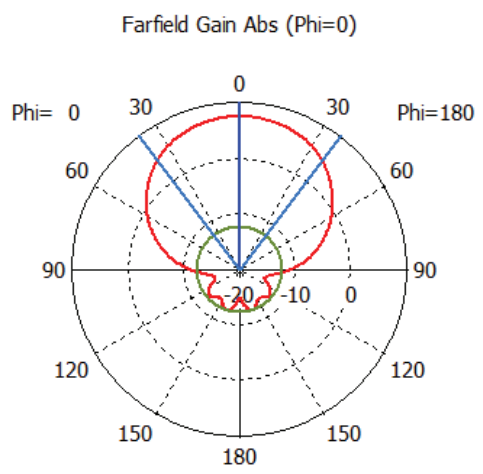

Theta / Degree vs. dB

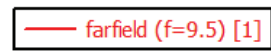

Frequency $=9.5 \mathrm{GHz}$

Main lobe magnitude $=7.44 \mathrm{~dB}$

Main lobe direction $=0.0 \mathrm{deg}$.

Angular width $(3 \mathrm{~dB})=74.1 \mathrm{deg}$.

Fig. 6: Radiation pattern for the single element microstrip patch antenna.

Table 3: Simulated results of the single element microstrip patch antenna in terms of gain $(\mathrm{dB})$, directivity $(\mathrm{dB})$, side-lobe level $(\mathrm{dB})$ and angular width (deg.).

\begin{tabular}{cc}
\hline Parameters & Optimized value \\
\hline Gain $(\mathrm{dB})$ & 7.44 \\
Directivity $(\mathrm{dB})$ & 8.54 \\
Side-lobe level (dB) & -12.345 \\
Angular width (deg.) & 74.1 \\
\hline
\end{tabular}




\subsection{Simulated Results of the Microstrip Patch Array Antenna}

As mentioned earlier, the single element antenna is then improved to work as an array with ten elements (Fig. 3) in order to improve some of its performance characteristics. Three types of excitation methods (uniform, binomial, and Tschebyscheff) are applied to the microstrip patch array antenna, which radiates in a directional pattern and is suitable to for use in X-band satellite communication. The simulation was run for two different spacings between the patches, i.e. $s=0.5 \lambda$ and $s=0.75 \lambda$, to observe the effect of spacing on the overall performances of the antenna. Figures 7 to 9 show the simulated return loss for the array antenna using uniform, binomial, and Tschebyscheff excitation signals. All three excitation methods resonated well at the targeted frequency of $9.5 \mathrm{GHz}$. Among the three excitation methods, the Tschebyscheff and binomial signals provided the best return loss with $S_{11}=-24.56 \mathrm{~dB}$, followed by the uniform signal with $S_{11}=-16.46 \mathrm{~dB}$.

Table 4 shows the simulated results of the microstrip patch array antenna using uniform, binomial, and Tschebycheff excitation methods for the two different spacings. The gain $(\mathrm{dB})$, directivity $(\mathrm{dB})$, side lobe level $(\mathrm{dB})$ and angular width (deg.) of the array antenna can be observed for each method. It can be seen that the uniform signal excitation produced the highest gain of $17.3 \mathrm{~dB}(s=0.75 \lambda)$ and $15.5 \mathrm{~dB}(s=0.5 \lambda)$, followed by Tschebycheff with $16.5 \mathrm{~dB}(s=0.75 \lambda)$ and $14.6 \mathrm{~dB}(s=0.5 \lambda)$. The binomial amplitude excitation produced the lowest gain among the three with $14.5 \mathrm{~dB}(s=0.75 \lambda)$ and $12.6 \mathrm{~dB}$ $(s=0.5 \lambda)$. Furthermore, among the three different types of excitation, the uniform signal excitation produced the highest directivity for both spacings between the patches with 18.5 $\mathrm{dB}(s=0.75 \lambda)$ and $16.8 \mathrm{~dB}(s=0.5 \lambda)$. This is followed by Tschebycheff with $17.7 \mathrm{~dB}(s=$ $0.75 \lambda)$ and $16 \mathrm{~dB}(s=0.5 \lambda)$, and binomial amplitude excitation with the lowest directivity among the three, with $15.8 \mathrm{~dB}(s=0.75 \lambda)$ and $14 \mathrm{~dB}(s=0.5 \lambda)$.

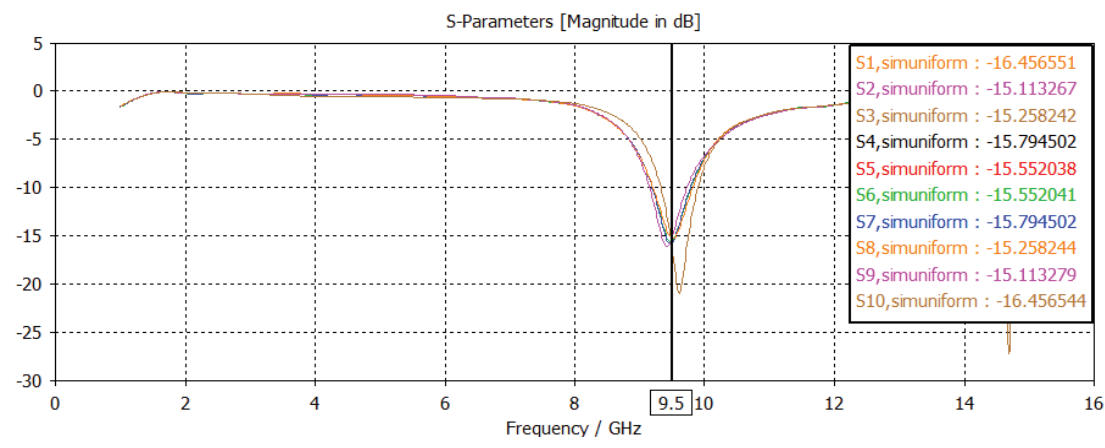

(a)

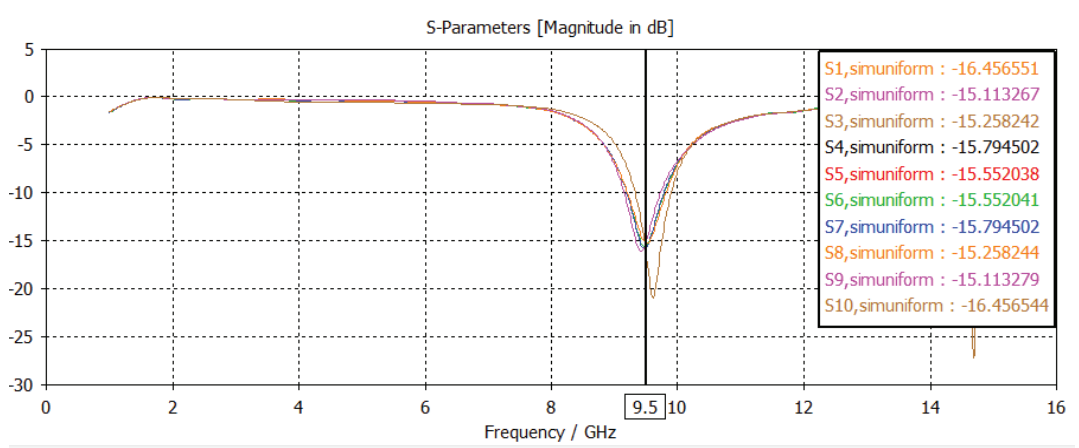

(b)

Fig. 7: Return loss for uniform excitation signal with (a) $s=0.5 \lambda$ and (b) $s=0.75 \lambda$. 


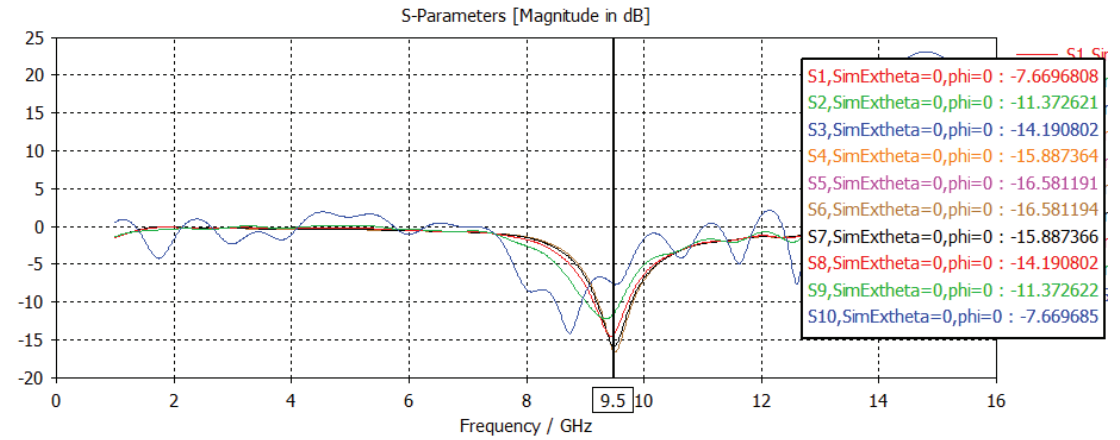

(a)

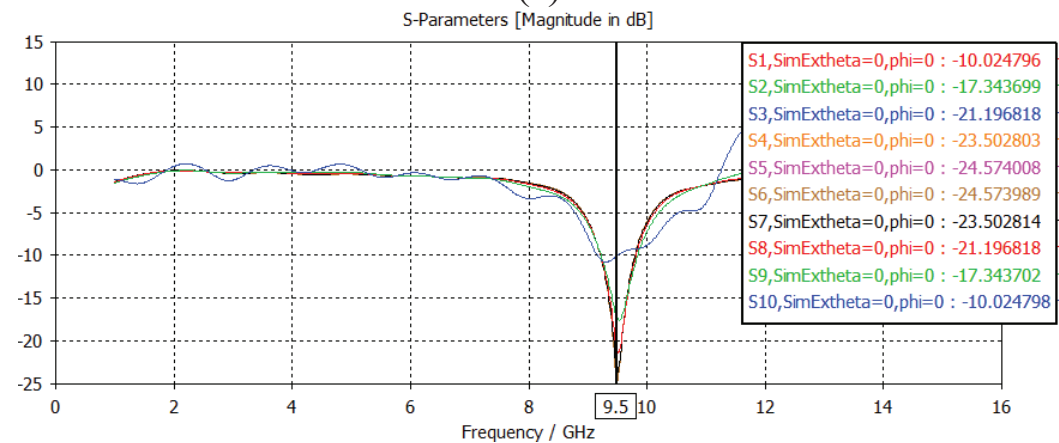

(b)

Fig. 8: Return loss for binomial excitation signal with (a) $s=0.5 \lambda$ and (b) $s=0.75 \lambda$.

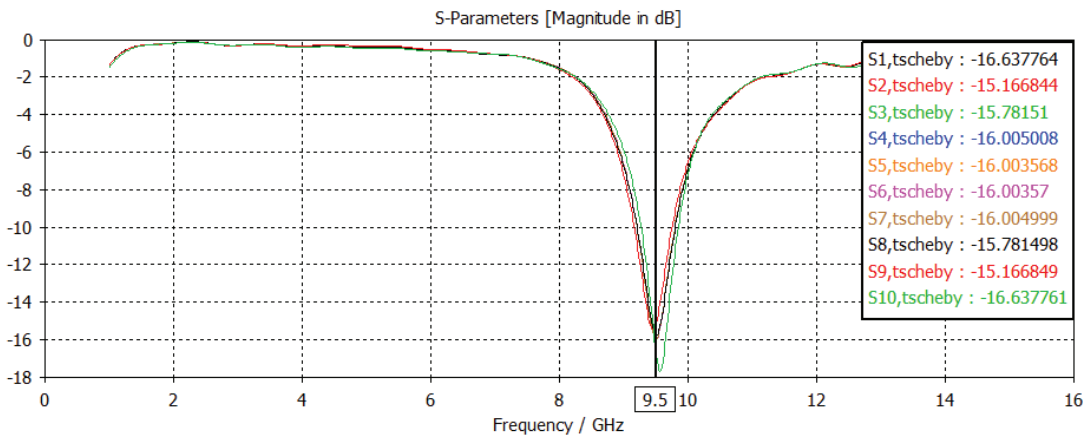

(a)

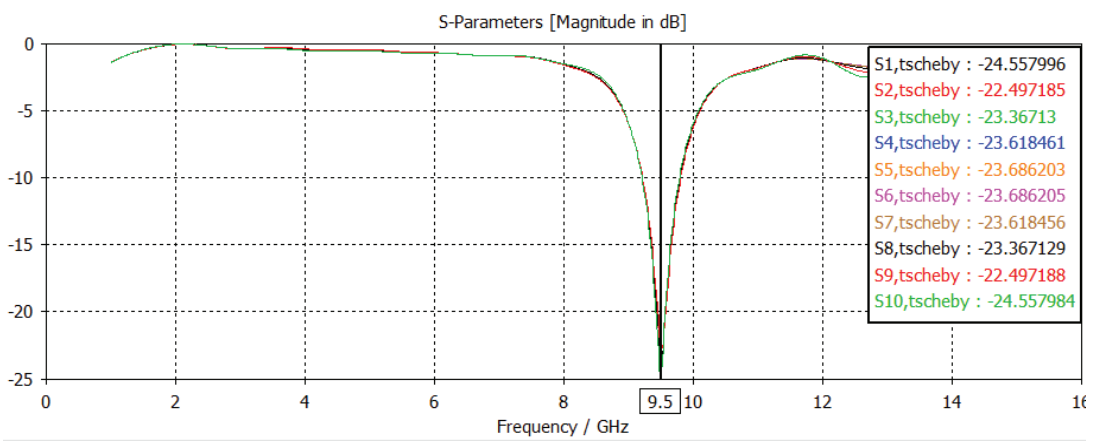

(b)

Fig. 9: Return loss for Tschebyscheff excitation signal with (a) $s=0.5 \lambda$ and (b) $s=0.75 \lambda$. 
Table 4: Simulated results of the microstrip patch array antenna in terms of gain $(\mathrm{dB})$, directivity $(\mathrm{dB})$, side lobe level $(\mathrm{dB})$ and angular width (deg.) using uniform, binomial and Tschebycheff excitation signals with $s=0.5 \lambda$ and $s=0.75 \lambda$.

\begin{tabular}{cccccccc}
\hline \multirow{2}{*}{ Excitation method } & \multicolumn{2}{c}{ Uniform } & \multicolumn{2}{c}{ Binomial } & \multicolumn{2}{c}{ Tschebyscheff } \\
Spacing (mm) & $\mathbf{0 . 5} \boldsymbol{\lambda}$ & $\mathbf{0 . 7 5} \boldsymbol{\lambda}$ & $\mathbf{0 . 5} \boldsymbol{\lambda}$ & $\mathbf{0 . 7 5} \boldsymbol{\lambda}$ & $\mathbf{0 . 5} \boldsymbol{\lambda}$ & $\mathbf{0 . 7 5} \boldsymbol{\lambda}$ \\
\hline Gain (dB) & 15.5 & 17.3 & 12.6 & 14.5 & 14.6 & 16.5 \\
Directivity (dB) & 16.8 & 18.5 & 14 & 15.8 & 16 & 17.7 \\
Side lobe level (dB) & 2.2 & 4.2 & -55.6 & -32.1 & -17.3 & -14.2 \\
Angular width (deg.) & 10.0 & 6.7 & 19.9 & 13.3 & 12.8 & 8.6 \\
\hline
\end{tabular}

In terms of side lobe level, binomial amplitude excitation exhibits the lowest level with $-55.6 \mathrm{~dB}(s=0.5 \lambda)$ and $-32.1 \mathrm{~dB}(s=0.75 \lambda)$ as shown in Fig. 11. This is followed by Tschebycheff with $-17.3 \mathrm{~dB}(s=0.5 \lambda)$ and $-14.2 \mathrm{~dB}(s=0.75 \lambda)$ as shown in Fig. 12. The uniform excitation signal exhibits the highest level of side lobes (which resulted the poorest performance) with $2.2 \mathrm{~dB}(s=0.5 \lambda)$ and $4.2 \mathrm{~dB}(s=0.75 \lambda)$ as shown in Fig. 10.

Furthermore, in terms of beam width, binomial amplitude excitation produces the widest angular width with $19.9 \mathrm{deg} .(s=0.5 \lambda)$ and $13.3 \mathrm{deg}$. $(s=0.75 \lambda)$ among the three amplitude excitation methods. It should be noted that the beam width of the main lobe must be as narrow as possible in the X-band satellite communication system. Therefore, uniform and Tschebycheff methods are more preferable than the binomial method in this case.

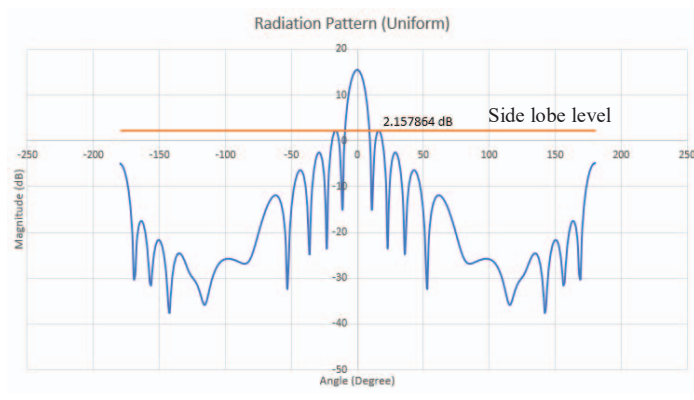

(a)

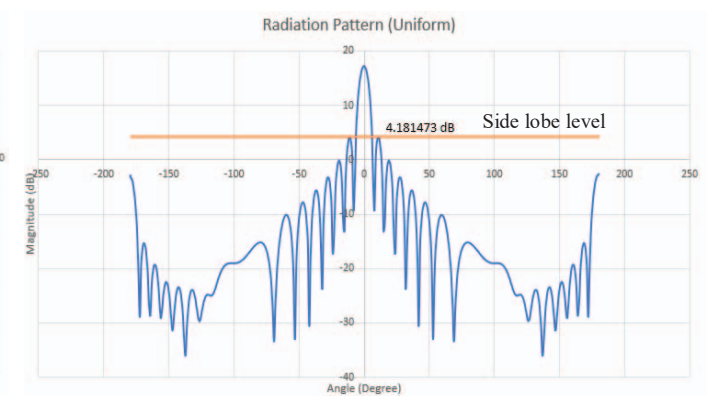

(b)

Fig. 10: Side lobe level for uniform excitation signal with (a) $s=0.5 \lambda$ and (b) $s=0.75 \lambda$.

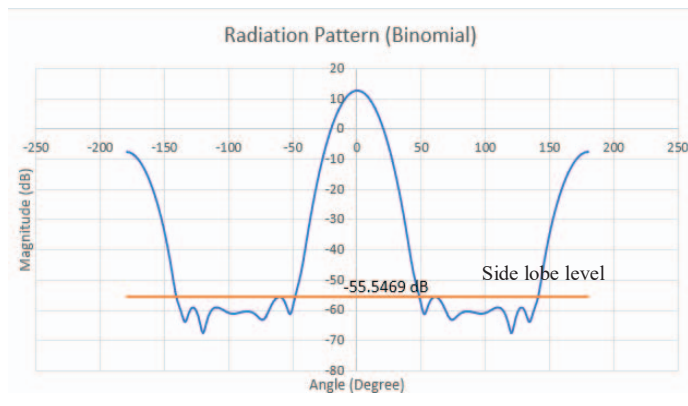

(a)

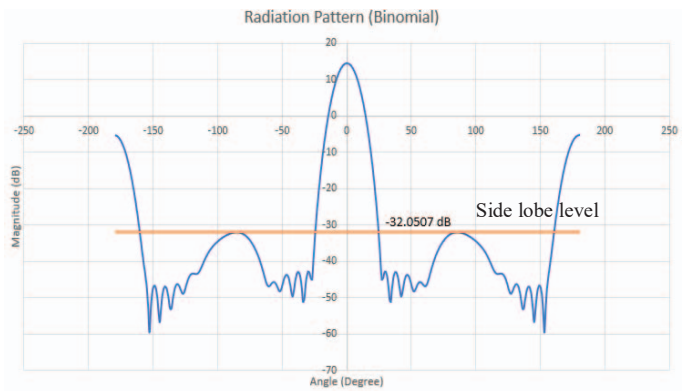

(b)

Fig. 11: Side lobe level for binomial excitation signal with (a) $s=0.5 \lambda$ and (b) $s=0.75 \lambda$. 


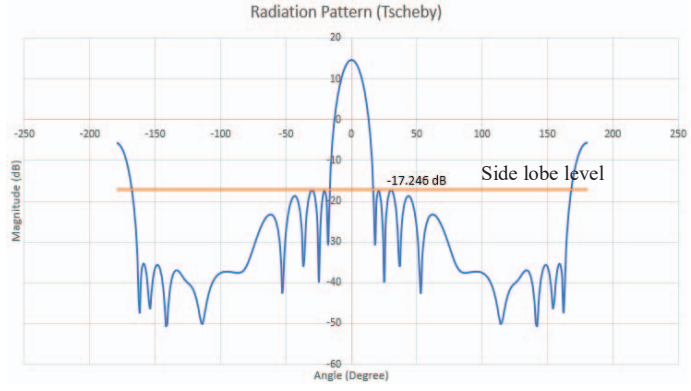

(a)

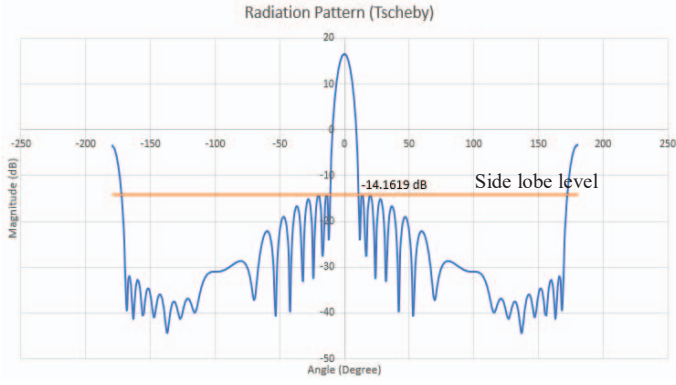

(b)

Fig. 12: Side lobe level for Tschebycheff excitation signal with (a) $s=0.5 \lambda$ and (b) $s=0.75 \lambda$.

Table 5 shows the radiation pattern of the microstrip patch array antenna with uniform, binomial, and Tschebyscheff excitation methods, at two different spacings of $s=0.5 \lambda$ and $s=0.75 \lambda$. Based on these results, the uniform and Tschebyscheff amplitude excitation methods produced the narrowest beam width, which is parallel to their high directivity and gain. However, they also produced the highest side lobe levels, which could risk the signal to be intercepted by neighbouring satellites through the side lobes. The binomial excitation method produced the widest beam width among the three, but with better side lobe level suppression, which will reduce the risk for the signal being intercepted.

Table 5: Radiation pattern of the microstrip patch array antenna with uniform, binomial and Tschebyscheff excitation signal, at two different spacing of $s=0.5 \lambda$ and $s=0.75 \lambda$.

\begin{tabular}{|c|c|c|}
\hline \multirow{2}{*}{$\begin{array}{l}\text { Excitation } \\
\text { Method }\end{array}$} & \multicolumn{2}{|l|}{ Radiation Pattern } \\
\hline & $s=0.5 \lambda$ & $s=0.75 \lambda$ \\
\hline Uniform & $m=0$ & \\
\hline Binomial & $=0$ & \\
\hline Tschebyschef & no. & \\
\hline
\end{tabular}


Table 6 concludes the contribution of this work in comparison to previous work done by others [2, 8-12]. By observing the side lobe level of each proposed antenna in the previous work, we can assume that the produced range of side lobe level is in between -10 $\mathrm{dB}$ to $-20 \mathrm{~dB}$. Through this research, we have proven that the side lobe level can be improved using three different excitation methods. In this work, the side lobe level improved from $4.2 \mathrm{~dB}$ to $-32.1 \mathrm{~dB}$ using binomial excitation and from 4.2 to $-14.2 \mathrm{~dB}$ using Tschebycheff. Unfortunately, this is gained at the cost of reduced gain and directivity by changing the excitation method from a uniform method to a non-uniform method (binomial and Tschebycheff).

Table 6: Contribution of this work in comparison with previous work [2, 8-12].

\begin{tabular}{|c|c|c|c|c|c|c|c|}
\hline Authors & $\begin{array}{l}\text { Antenna } \\
\text { proposed }\end{array}$ & $\begin{array}{l}\text { No. of } \\
\text { element }\end{array}$ & $\begin{array}{l}\text { Freq. } \\
\text { band }\end{array}$ & $\begin{array}{l}\text { Resonant } \\
\text { freq. } \\
(\mathrm{GHz}) \\
\end{array}$ & $\begin{array}{l}\text { Size } \\
(\mathrm{mm})\end{array}$ & $\begin{array}{l}\text { Gain } \\
(\mathrm{dB})\end{array}$ & $\begin{array}{l}\text { Side lobe } \\
\text { level }(\mathrm{dB})\end{array}$ \\
\hline $\begin{array}{l}\text { Chaurasia et } \\
\text { al. }(2017)\end{array}$ & $\begin{array}{l}\text { Microstrip } \\
\text { antenna }\end{array}$ & 1 & $\mathrm{X}$ & 11 & $30(\mathrm{~W}) \times 35(\mathrm{~L})$ & 10.38 & N/A \\
\hline \multirow[t]{2}{*}{$\begin{array}{l}\text { Mao et al. } \\
(2017)\end{array}$} & $\begin{array}{l}\text { Dual-band } \\
\text { shared- }\end{array}$ & $4 \times 4$ & $\mathrm{X}$ & 8.2 & $110(\mathrm{~W}) \times 110(\mathrm{~L})$ & 17.5 & -15 \\
\hline & $\begin{array}{l}\text { aperture CP } \\
\text { array } \\
\text { antenna }\end{array}$ & $2 \times 2$ & $\mathrm{C}$ & 5.3 & $110(\mathrm{~W}) \times 110(\mathrm{~L})$ & 14.5 & -12.5 \\
\hline $\begin{array}{l}\text { Huang et al. } \\
(2017)\end{array}$ & $\begin{array}{l}\text { Circularly- } \\
\text { polarized } \\
(\mathrm{CP}) \text { planar } \\
\text { patch } \\
\text { antenna } \\
\text { array }\end{array}$ & $16 \times 6$ & $\mathrm{Ku}$ & - & $340(\mathrm{~W}) \times 137(\mathrm{~L})$ & 26.4 & N/A \\
\hline \multirow{2}{*}{$\begin{array}{l}\text { Suryana and } \\
\text { Madiawati } \\
(2016)\end{array}$} & \multirow{2}{*}{$\begin{array}{l}\text { Antenna } \\
\text { microstrip } \\
\text { array }\end{array}$} & \multirow[t]{2}{*}{$2 \times 16$} & $\mathrm{Ku}$ & 14 & $20(\mathrm{~W}) \times 5(\mathrm{~L})$ & 17.91 & $\mathrm{~N} / \mathrm{A}$ \\
\hline & & & $\mathrm{Ku}$ & 12 & $20(\mathrm{~W}) \times 5(\mathrm{~L})$ & 18.69 & $\mathrm{~N} / \mathrm{A}$ \\
\hline $\begin{array}{l}\text { So and Chan } \\
(2016)\end{array}$ & $\begin{array}{l}\text { Circularly } \\
\text { polarized } \\
\text { patch } \\
\text { antenna } \\
\text { array }\end{array}$ & $16 \times 16$ & $\mathrm{Ku}$ & 12 & N/A & $>30$ & N/A \\
\hline $\begin{array}{l}\text { Chen and Yan } \\
(2016)\end{array}$ & $\begin{array}{l}\text { Microstrip } \\
\text { phased } \\
\text { array } \\
\text { antenna }\end{array}$ & $8 \times 12$ & $\mathrm{~K}$ & 24 & N/A & 25 & -18 \\
\hline $\begin{array}{l}\text { This work } \\
\text { (tschebycheff) }\end{array}$ & $\begin{array}{l}\text { Microstrip } \\
\text { patch array } \\
\text { antenna }\end{array}$ & $1 \times 10$ & $\mathrm{X}$ & 9.5 & $\begin{array}{c}285(\mathrm{~W}) \times \\
59.275(\mathrm{~L})\end{array}$ & 16.5 & -14.2 \\
\hline $\begin{array}{l}\text { This work } \\
\text { (binomial) }\end{array}$ & $\begin{array}{l}\text { Microstrip } \\
\text { patch array } \\
\text { antenna }\end{array}$ & $1 \times 10$ & $X$ & 9.5 & $\begin{array}{l}285(\mathrm{~W}) \times \\
59.275(\mathrm{~L})\end{array}$ & 14.5 & -32.1 \\
\hline $\begin{array}{l}\text { This work } \\
\text { (uniform) }\end{array}$ & $\begin{array}{l}\text { Microstrip } \\
\text { patch array } \\
\text { antenna }\end{array}$ & $1 \times 10$ & $\mathrm{X}$ & 9.5 & $\begin{array}{l}285(\mathrm{~W}) \times \\
59.275(\mathrm{~L})\end{array}$ & 17.3 & 4.2 \\
\hline
\end{tabular}

Practically, implementing the non-uniform excitation method would be difficult to achieve and maintain due to its variation in the excitation amplitude, especially for the 
binomial excitation method compared to the Tschebycheff excitation method as in Table 7.

Table 7: Uniform, Tschebyscheff and binomial excitation coefficients.

\begin{tabular}{lccc}
\hline & Uniform & $\begin{array}{c}\text { Tschebyscheff } \\
\text { (with major-to- } \\
\text { minor lobe ratio of } \\
\text { 30 dB) }\end{array}$ & Binomial \\
\hline Port1 & 1 & 2.5177 & 1 \\
Port2 & 1 & 4.2036 & 9 \\
Port3 & 1 & 6.5436 & 36 \\
Port4 & 1 & 8.5866 & 84 \\
Port5 & 1 & 9.78006 & 126 \\
Port6 & 1 & 9.78006 & 126 \\
Port7 & 1 & 8.5866 & 84 \\
Port8 & 1 & 6.5436 & 36 \\
Port9 & 1 & 4.2036 & 9 \\
Port10 & 1 & 2.5177 & 1 \\
\hline
\end{tabular}

\section{CONCLUSION}

In conclusion, a microstrip patch array antenna for side lobe suppression has been developed for use in X-band communication at $9.5 \mathrm{GHz}$. The antenna performance such as $S_{11}$, gain, directivity, side lobe level and angular width have been investigated and discussed. The antenna was first designed as a single element and further modified to work as an array in order to increase the gain and directivity, and also to reduce the beam width, which is convenient for transmission of data for specific satellite communication in the Xband region. Furthermore, the proposed array antenna has been simulated using three different signal excitation methods, which are uniform, binomial, and Tschebyscheff, at two different spacing of $s=0.5 \lambda$ and $s=0.75 \lambda$. Based on the radiation pattern produced, the Tschebycheff amplitude excitation method provides the best antenna performance compared to the other two excitation methods. The proposed antenna configuration has met all the objectives set (i.e. having low side-lobes level of $-14.2 \mathrm{~dB}$, an acceptable high gain of $16.5 \mathrm{~dB}$, a directivity of $17.7 \mathrm{~dB}$, an angular width of $8.6 \mathrm{deg}$., and a compact structure of $285 \mathrm{~mm} \times 59.275 \mathrm{~mm}$ ), which is convenient for mobility purposes. Therefore, it can be summarized that our microstrip patch array antenna can be an alternative choice for a future X-band antenna to replace the currently used reflector antennas that are massive, heavy, and produce very high side lobe levels.

\section{ACKNOWLEDGEMENT}

This research was supported by International Islamic University Malaysia and Ministry of Education Malaysia through Fundamental Research Grant Scheme for Research Acculturation of Early Career Researchers FRGS-RACER (RACER19-053-0053) (RACER/1/2019/TK04/UIAM//1). 


\section{REFERENCES}

[1] Balanis CA. (2016) Antenna Theory - Analysis and Design. Hoboken, John Wiley \& Sons, Inc.

[2] Chaurasia RK, Mathur V, Saini AK, Mukherji R. (2017) Design and analysis of microstrip antenna for X-Band communication. IUP Journal of Telecommunications, 9(3): 38-43.

[3] Mohamad S, Cahill R. (2017) Spiral Antenna with reconfigurable HIS using liquid crystals for monopulse radar application. In Proceedings of the IEEE Conference on Antenna Measurements and Applications (CAMA); pp 55-58.

[4] Mohamad S, Cahill R, Fusco V. (2015) Tri-band HIS Backed Spiral Antenna for Wireless LAN Applications. Microwave and Optical Technology Letters, 57(5):1116-1121.

[5] Balanis CA. (2012) Advanced Engineering Electromagnetics. Hoboken, John Wiley \& Sons, Inc.

[6] Rahman DA, Mohamad S, Abdul Malek NF, Rahman DA, Zabri SN. (2018) A wideband mm-wave printed dipole antenna for $5 \mathrm{G}$ applications. Indonesian Journal of Electrical Engineering and Computer Science, 10(3): 943-950.

[7] Ahmad Mustafa A M, Mohamad S, Abdul Malek NF, Mohd Isa FN, Md. Rafiqul Islam. (2018) A wideband circularly-polarized spiral antenna for Cube Sat application. Journal of Telecommunication, Electronic and Computer Engineering, 10(1-8): 17-20.

[8] Mao CX, Gao S, Wang Y, Chu QX, Yang XX. (2017) Dual-band circularly polarized shared-aperture array for $\mathrm{C}-\mathrm{X}$ - band satellite communications. IEEE Transaction and Propagation, 65(10): 5171-5178.

[9] Huang J, Lin W, Qiu F, Jiang C, Lei D, Guo YJ. (2017) A low profile, ultra-lightweight, high efficient circularly-polarized antenna array for $\mathrm{Ku}$ band satellite applications. IEEE Access, 5: 18356-18365.

[10] Suryana J, Madiawati H. (2016) Design and implementation of mobile antenna VSAT with microstrip array based at Ku band frequency. In Proceedings of the $10^{\text {th }}$ International Conference on Telecommunication Systems Services and Applications (TSSA).

[11] So KK, Chan CH. (2016) Circularly polarized patch antenna array for satellite communication in $\mathrm{Ku}$ band. In Proceedings of the IEEE $10^{\text {th }}$ European Conference on Antennas and Propagation (EuCAP); pp. 1-4.

[12] ChenLJ, Yan MJ. (2016) Design of $24 \mathrm{GHz}$ microstrip phased array antennas with low sidelobe. In Proceedings of the IEEE International Conference on Electronic Information and Communication Technology. 